\title{
SOME PHYSICAL AND CHEMICAL PROPERTIES OF CERTAIN SNAKE OILS
}

\section{B. Pollard and David C. Young, Jr. University of Florida}

At the beginning of the hibernation period, well-fed snakes have fat lobes deposited along both sides of the intestines in the area between the stomach and vent. This fat supply is nearly or completely exhausted at the end of the hibernation period.

Although snake oil has been used and discussed for generations, very little information concerning its composition is available in the literature. Most of the publications which have dealt with physical and chemical properties of snake oils have neglected to state whether the oils were obtained from the whole snakes or from the lobes. For this reason the available data have little value for purposes of comparison with respect to species differences.

Pollard and McLaughlin ${ }^{1}$ reported physical and chemical properties of oils obtained from the lobes of the boa constrictor (Constrictor constrictor), prairie rattler (Crotalus viridus viridus), and the moccasin (Agkistrodon piscivorus). In continuation of their work, this paper reports the results of a study of the oils obtained from the lobes of the eastern diamond-back rattler (Crotalus adamanteus), western diamond-back rattler (Crotalus atrox), banded water snake (Natrix sipedon pictiventris) and Congo water snake (Natrix cyclopian floridana).

\section{EXPERIMENTAI}

The cold-pressing method of extraction, with the use of the Carver laboratory press, was employed for all samples, since it eliminates changes in the lipoids which are often caused by heat and oxidation. Several snakes of each species were butchered soon after capture and the lobes of the respective species pooled. Lobes which were not processed immediately were kept frozen until the beginning of the purification procedure.

The lobes were dried on filter paper, and all connective tissues and blood vessels were carefully removed. They were then

${ }^{1}$ C. B. Pollard and Joseph McLaughlin, Jr., The Journal of the American Oil Chemists' Society, Vol. XXVII, No. 10, 393, October 1950. 


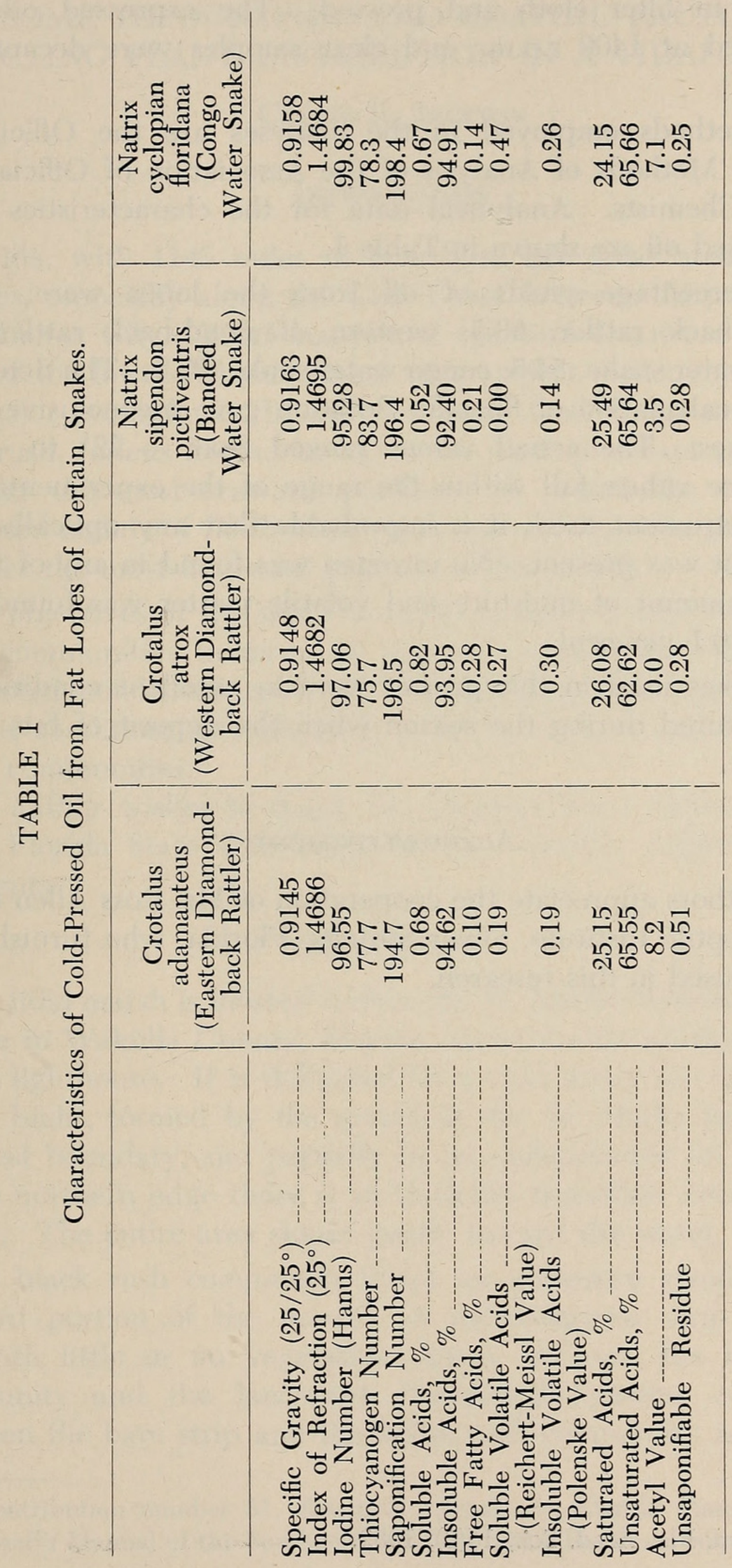


wrapped in filter cloth and pressed. The expressed oils were centrifuged at 1400 r.p.m., and clear samples were decanted for analysis.

The methods employed in the analyses are the Official and Tentative Methods of Analysis of the Association of Official Agricultural Chemists. Analytical data for the characteristics of the cold-pressed oil are shown in Table 1.

The percentage yields of oil from the lobes were: eastern diamond-back rattler, 63.5; western diamond-back rattler, 50.0; banded water snake, 54.5; congo water snake, 65.3. The determination and calculation of Specific Rotation gave inconclusive results in all cases. The actual values ranged from $-.22^{\circ}$ to $+0.06^{\circ}$. Since these values fall within the range of the experimental error of the instrument used, it is improbable that any optically active component was present. No nitrogen was found in any of the oils and the amount of moisture and volatile matter was found to be less than 0.1 per cent.

All snakes used in this project were in excellent condition and were captured during the season when the deposit of fats is at a maximum.

\section{ACKNOWLEDGMENT}

The authors appreciate the cooperation of Mr. Ross Allen of Ross Allen's Reptile Institute, Silver Springs, Florida, who furnished the fat lobes used in this research.

Quart. Journ. Fla. Acad. Sci., 15(3), 1952. 


\section{$2 \mathrm{BHL}$ Biodiversity Heritage Library}

Pollard, C B and Young, David C. 1952. "Some physical and chemical properties of certain snake oils." Quarterly journal of the Florida Academy of Sciences 15, 134-136.

View This Item Online: https://www.biodiversitylibrary.org/item/129662

Permalink: https://www.biodiversitylibrary.org/partpdf/91837.

\section{Holding Institution}

Smithsonian Libraries

\section{Sponsored by}

Biodiversity Heritage Library

\section{Copyright \& Reuse}

Copyright Status: In Copyright. Digitized with the permission of the rights holder.

License: http://creativecommons.org/licenses/by-nc-sa/3.0/

Rights: https://www.biodiversitylibrary.org/permissions/

This document was created from content at the Biodiversity Heritage Library, the world's largest open access digital library for biodiversity literature and archives. Visit BHL at https://www.biodiversitylibrary.org. 